\title{
SOSIALE REKENINGKUNDE: AGTERGROND EN PROBLEMATIEK
}

\author{
D.S. Lubbe \\ Dept. Rekeningkunde en hoof van die \\ Gencor Navorsingseenheid vir Ouditkunde \\ Universiteit van die Oranje-Vrystaat \\ BLOEMFONTEIN \\ en \\ Q. Vorster \\ Skool vir Rekenmeestersopleiding \\ Universiteit van Pretoria \\ PRETORIA
}

\begin{abstract}
The necessity for the accountant to report on the social responsibility of an enterprise, and in particular its responsibility towards the environment, has come into prominence lately. Nevertheless, there is probably no other field in accounting in which the accounting profession has failed to show progress for so long.

Since the time of the Industrial Revolution social accounting has been regarded as essential, but especially during the late sixties and the seventies various authors have endeavoured to develop techniques and models for social accounting. Some of the most impontant problems encountered have however been the lack of acceptable uniform definitions, the fact that the accounting profession mostly reacts pragmatically and that as a result of pressure towards rapid development, fundamental questions have not been fully considered.
\end{abstract}

The accounting profession should contribute to the development and application of social accounting and social audit as pan of an interdisciplinary group of experts.

\section{INLEIDING}

Sedert Pacioli se boek oor die dubbelinskrywing in 1494 die lig gesien het, moes daar dikwels in die rekeningkunde antwoorde gevind word vir nuwe vraagstukke wat voortgevloei het uit moderne en ontwikkelende handelspraktyke. Daar is waarskynlik geen ander gebied in die rekeningkunde waar noemenswaardige vordering die rekenmeestersprofessie reeds so lank ontwyk as juis dié van sosiale rekeningkunde nie. Volgens Hurley (1982:142) sien sekere leiers van die professie dit as een van die grootste toekomsuitdagings, terwyl andere maan dat die rekenmeester nie daarby betrokke mag raak of dit bloot afmaak as 'n 'dead issue'nie. 
Gedurende die laaste paar jaar was daar wêreldwyd 'n toenemende bewuswording van natuurlike hulpbronne. Uitdrukkings soos green assets, green consciousness, think green, green reporting, green audit, green consumerism, green revolution en green consumer goods is binne ' $n$ baie kort tydjie in die algemene spreektaal opgeneem en talle artikels verskyn tans in vaktydskrifte oor sosiale verantwoordelikheid en die tekortkominge van die finansiële rekeningkunde om aan 'groen verslaglewering' reg te laat geskied.

Deur die jare het verskeie skrywers gepoog om terme soos sosiale verantwoordelikheid en sosiale rekeningkunde te definieer. Eenstemmigheid oor die onderskeie definisies het egter steeds uitgebly. Hurley (1982:40) verklaar dat "this area has become a definitional nightmare". Dit is nie die doel met hierdie artikel om 'n eenvormige definisie vir die term sosiale rekeningkunde te verskaf nie, aangesien dit 'n artikel op sigself regverdig. Daar word gevolglik volstaan met die volgende twee omskrywings.

Mathews (1984:8) definieer die term as

(v)oluntary disclosure of information, both qualitative and quantitative, made by organisations to inform or influence a range of audiences. The quantitative disclosures may be in financial or non-financial terms.

In 'n geskrif van die Britse owerheid (Mathews 1984:16) word daar soos volg na sosiale rekeningkunde verwys:

\begin{abstract}
Social accounting is a term which covers a range of ideas, many of which are at a very carly stage of development. At its simplest, it involves reporting, largely on an ad hoc basis, on individual items such as anti-polution or health and safety measures which may be of greater importance for their social impact than for their financial effects on the company.
\end{abstract}

In hierdie artikel, die eerste van drie, word die historiese ontwikkeling van sosiale verantwoordelikheid en sosiale rekeningkunde kortliks toegelig. In twee verdere artikels word 'n aantal modelle en tegnieke van sosiale rekeningkunde wat reeds ontwikkel is, krities toegelig en word enkele riglyne gestel vir toekomstige navorsing oor sosiale rekeningkunde.

\title{
2. DIE ONTWIKKELING VAN SOSIALE VERANTWOORDELIKHEID EN SOSIALE REKENINGKUNDE
}

Sedert sy ontstaan het die Rooms-Katolieke Kerk sy invloed op vele terreine van die samelewing laat geld. Bauer en Fenn (1972:4) meld dat die kerk vir eeue die "watchdog of businessmen" was. Die Industriële Revolusie was in vele opsigte 'n keerpunt in die wêreldgeskiedenis en het ook die groot invloed van die kerk op die handel finaal verbreek. Sosiale verantwoordelikheid is toe gesien as massaproduksie teen die laags 
moontlike prys. Daar is geglo dat felle mededinging die sleutel sou wees tot 'n beter ekonomie en 'n beter gemeenskap. Die laissez faire-benadering van Adam Smith het groot byval gevind en van sosiaal-verantwoordelike optrede was daar min sprake. Die gees van kapitalisme wat volgens Heaton (1965:185) in daardie tyd geheers het, het gelei tot "striving for profit without limit, regardless of social consequences and free from control by church, state, or any other restraining force".

Voor die Industriële Revolusie was daar ook gevalle waar besoedeling voorgekom het. Dié besoedeling en uitputting van hulpbronne was egter baie beperk weens die klein wêreldpopulasie en die primitiewe werktuie waarmee relatief min skade aan die omgewing aangerig kon word. Die Industriële Revolusie het egter tot gevolg gehad dat werktuie en masjiene ontwikkel is wat 'n wesenlike invloed op die mens en sy omgewing gehad het. Rubenstein (1989:31) meld dat

\footnotetext{
Adam Smith told us the invisible hand of self-interest would guide resources to their best use in the creation of wealth. With hindsight, wc can point to the Industrial Revolution as the source of the gap between the ordered world of double-entry bookkeeping and the modern reality of large-scale pollution and its attendant costs. The period brought with it the first evidence of unplanned social costs: double-entry accounting couldn't handle pollution from tall smokestacks, the dislocation of human life and the consequences of child labour.
}

Gedurende die eeue wat op die Industriële Revolusie gevolg het, het verskeie ekonome, politici, sakemanne en rekenmeesters hulle uitgespreek ten gunste van die aanvaarding van sosiale verantwoordelikheid deur ondernemings en 'n beroep gedoen dat tegnieke ontwikkel moet word om hierdie sosiale verantwoordelikheid te kwantifiseer. Baie ondernemings reik reeds vir etlike jare saam met hul finansiële jaarstate 'n verslag oor die nakoming van hul sosiale verantwoordelikhede uit. In sommige gevalle is sodanige verslae reeds omvangryker as die jaarstate. Verskeie van hierdie verslae oor sosiale verantwoordelikheid het al aangedui dat daar'n dringende behoefte is aan 'n eenvormige stelsel van verslagdoening en die onafhanklike nagaan (ouditering) daarvan (vergelyk Lubbe, 1988:47-50).

Veral gedurende die laat sestigerjare en die sewentigerjare het verskeie skrywers gepoog om tegnieke en modelle van sosiale rekeningkunde te ontwikkel.

\section{PROBLEME IN DIE WEG VAN DIE ONTWIKKELING VAN 'N TEGNIEK VAN SOSIALE REKENINGKUNDE}

In paragraaf 2 is daarop gewys dat daar meer as 'n dekade gelede reeds verskeje modelle en tegnieke van sosiale rekeningkunde ontwikkel is. Die rede waarom hierdie modelle en tegnieke nie toe reeds algemene byval gevind het nie, is waarskynlik dat die 
konsep van sosiale verantwoordelikheid in daardie stadium nog nie so algemeen deur ondernemings aanvaar is as tans nie. Tans is sosiale verantwoordelikheid in so 'n mate aanvaar dat die meeste groot ondernemings dit reeds beskou as deel van hulle basiese sakefilosofie. (Vergelyk Lubbe (1991:22-42) vir argumente ten gunste van en teen die aanvaarding van sosiale verantwoordelikheid as doelstelling van die onderneming.)

Dit is egter nie net ondernemings wat gedurende die laat sestiger- en die sewentigerjare die konsep van sosiale verantwoordelikheid en sosiale rekeningkunde in 'n groot mate verwerp het nie, maar ook rekenmeesters het min belangstelling daarin getoon. Skrywers soos Gray (1990:65-68) en Bebbington et al. (1990:17-20) verklaar dat die geweidige hernieude belangstelling in sosiale rekeningkunde net voortbou op die grondslae wat reeds in die sestiger-en sewentigerjare gelê is.

Een van die belangrikste probleme in die weg van sosiale rekeningkunde is moontlik die gebrek aan aanvaarbare eenvormige definisies. Daar is reeds in paragraaf 1 verwys na uiteenlopende en selfs teenstrydige definisies met betrekking tot sosiale rekeningkunde en verwante terme en die feit dat weinig indien enige skrywers uitspel wat hul definisies ten grondslag lê. Hierdie probleem is egter nie uniek nie. Navorsing oor sosiale rekeningkunde is reeds vir ongeveer twintig jaar aan die gang. Daarenteen strek die ontwikkeling van finansiële rekeningkunde reeds oor eeue en nog bestaan daar geen eenvormige definisies van byvoorbeeld die grondliggende rekeningkundige begrippe nie.

Tinker $(1985: 205,206)$ beskuldig rekenmeesters daarvan dat hulle pragmaties is in hul denke en nie maklik betrokke wil raak by verrykende vernuwing en veranderinge nie. Hy stel dit so:

\footnotetext{
In an all-too-brief literature review, we have reconceptualized accounting by enriching it with work from economics, anthropology, sociology, philosophy, and other disciplines. This reconceptualization, which could form an entirely new basis for accounting studies, has enabled us to see accounting not as mere bookkeeping and record keeping, but as capitalism's prime adjudicator in social conflict. Regrettably, intellectual eclecticism is not the norm in accounting the socially creative potential of accounting ... are not serious agenda items for the profession, either in practice, in education, or in research. In fact, an ethos that is completely antithetical to this kind of social creativity currently prevails in accounting.
}

Hurley (1982:69) meld dat weens die druk uit verskeie oorde om binne 'n kort tydperk 'n stelsel van sosiale rekeningkunde te ontwikkel, hierdie terrein te vinnig ontwikkel het sonder dat wesenlike vraagstukke behoorlik deurdink is. Volgens hom het hierdie aspek aanleiding gegee tot antagonisme onder sakelui en andere jeens dit wat sosiale rekeningkunde ten grondslag lê.

Sterling (in Hurley, 1982:151) meen dat navorsing op die gebied van die rekening- 
kunde grootliks weg van die rekeningkundige praktyk en opleiding plaasvind en dat "this isolation promotes a false harmony that makes it difficult for the profession to adequately address new issues such as Social Responsibility Accounting".

'n Aanvaarbare metode om sosiale verantwoordelikheid te kwantifiseer is waarskynlik die grootste enkele struikelblok in die weg van sosiale rekeningkunde. Stiner (1978:28) kom tot die gevolgtrekking dat "(u)nfortunately, dollars alone cannot measure human events ...".

In die lig daarvan dat die modelle van onder andere Linowes, Estes en Abt in verdere artikels behandel word, word dié aspek nie hier verder toegelig nie. 'n Laaste probleem is die verdeeldheid in rekenmeestersgeledere oor die professie se betrokkenheid by sosiale rekeningkunde en die sosiale oudit. Die rekenmeestersprofessie se rol in dié verband word vervolgens toegelig.

\section{SOSIALE VERANTWOORDING EN DIE REKENMEESTERSPROFESSIE}

Daar bestaan baie uiteenlopende menings oor die rekenmeestersprofessie se rol met betrekking tot sosiale verantwoordelikheid en veral met betrekking tot sosiale rekeningkunde. Marlin (1973:42) voer byvoorbeeld oortuigende argumente aan waarom die rekenmeestersprofessie betrokke moet raak by sosiale rekeningkunde. Hy kom tot die volgende slotsom:

No other group has the necessary patience and insight that accountants can bring to the messy details of actually measuring performance ... (u)ntil accountants become fully involved, social responsibility will remain a cliche.

Lynreg teenoor bogenoemde siening betoog Francis (1973:245 - 257) weer dat die rekenmeestersprofessie hom nie op die sosiale terrein moet begeef nie. Skrywers wat Francis se siening deel, gebruik veral die argument dat rekenmeesters nie oor die kundigheid en opleiding met betrekking tot sosiale verantwoordelikheid beskik nie. Hierdie argument word vervolgens ontleed.

Persone wat bogenoemde siening huldig, gaan van die veronderstelling uit dat die rekenmeestersprofessie alle verantwoordelikheid neem met betrekking tot die ontwikkeling van sosiale rekeningkunde en die uitvoering van 'n sosiale oudit. Dit is egter geensins die geval nie. Trouens, voorstanders van betrokkenheid deur die rekenmeestersprofessie by sosiale-verantwoordelikheidsvraagstukke erken deurgaans dat sosiale verantwoordelikheid en verwante aspekte interdissiplinêr van aard is en dat die rekeningkunde en ouditkunde slegs twee van vele dissiplines is wat 'n bydrae op dié gebied kan lewer. Abt (1977:218) het 'n insiggewende vloeidiagram opgestel van die 
verskillende dissiplines wat meehelp met die ontwikkeling van die sosiale rekeningkunde en sosiale oudit. Die vier grandparent disciplines wat bogenoemde begrippe ten grondslag lê, is volgens Abt se diagram die volgende:

- Toegepaste Wiskunde, Statistiek, Operasionele Navorsing

- Neoklassieke Ekonomie

- Sosiologie en Sosiale Sielkunde

- Politieke Wetenskap.

Rekeningkunde en ouditkunde is maar twee van die subdissiplines wat op Abt se diagram getoon word (vergelyk ook Fetyko, 1975:526). Stiner (1978:16) stel dit ook duidelik dat kundigheid vanuit verskeie dissiplines betrek moet word by die uitvoering van enige sosiale oudit.

Teenstanders van die argument dat die rekenmeester nie oor die nodige kundigheid en opleiding beskik nie, wys daarop dat die rekenmeestersprofessie juis hierdie tyd waarin daar nog baie onopgeloste vrae rondom aspekte van sosiale verantwoordelikheid bestaan, moet benut as 'n opleidingstydperk met betrekking tot die onderwerp. Tinker (1985:199 - 205) beskuldig die rekenmeestersprofessie van traagheid om nuwe terreine te betree en van wegskramming van verantwoordelikheid met betrekking tot sosiale vraagstukke.

Regrettably, intellectual eclecticism is not the norm in accounting ... Educators do not offer a
systematic study of social change and of the part that accounting has been - and could be -
playing in initiating change. Instead, a form of rote icarning dominates most levels of education:
students parrot Financial Accounting Standards Board rules and procedure without acquiring
the epistemological faculties needed to critically scrutinize this catechism ... Accounting does
not wait to be found or discovered, like an atomic particle or a pulsar; subjects like accounting
must be invented or created, and thus the pitiful intellectual state of a discipline is due to a
failure on the part of the inventors, not the object of the study.

Storey (1981:51) sluit ook by bogenoemde aan en wys daarop dat "(w)e are all prone to defend the status quo, which is known and comfortable, and to resist change, which is unknown and unsettling".

In die lig van die voorafgaande asook die feit dat baie kliënte van ouditeure sosiale verantwoordelikheid as 'n deel van hul bestuursfilosofie aanvaar het, kan die rekenmeestersprofessie eenvoudig nie afsydig laat staan teenoor sosiale verantwoordelikheid en aspekte daarvan nie. Die siening dat dit 'n interdissiplinêre studieveld is, word onderskryf.

Vervolgens word enkele verdere argumente aangevoer waarom dit noodsaaklik is dat die rekenmeestersprofessie deel vorm van 'n interdissiplinêre groep kundiges wat hulle 
beywer vir die ontwikkeling (en toepassing) van sosiale rekeningkunde en die sosiale oudit:

* Die rekenmeester kan as besondere kenner van die meting en kwantifisering van inligting ' $n$ groot bydrae lewer. Dieselfde argument geld ook met betrekking tot verslagdoening.

- Daar is baie raakvlakke tussen sosiale en finansiële rekeningkunde en die rekenmeester se kennis kan as 'n waardevolle skakel tussen die twee dissiplines dien.

- Die ouditeur se sin vir onafhanklikheid en objektiwiteit sal groter geloofwaardigheid aan 'n stelsel van sosiale rekeningkunde en 'n daarmee gepaardgaande sosiale oudit verleen.

* Daar is 'n sekere mate van oorvleueling tussen sosiale rekeningkunde en oudit en finansiële rekeningkunde en oudit. Die rekenmeester se betrokkenheid sal dus duplisering van werk kan voorkom.

- Sosiale rekeningkunde en sosiale oudit verg 'n groot mate van agtergrondskennis van 'n onderneming. Die ouditeur se kennis hiervan kan van groot waarde wees.

* Die ouditeur is reeds in 'n sekere mate gemoeid met die uitvoering van 'n 'sosiale oudit' deur byvoorbeeld toe te sien dat kliënte aan sekere wetlike bepalinge voldoen. Die ouditeursprofessie beskik dus reeds oor ondervinding op hierdie terrein.

Daar word volstaan met Hurley (1982:179) se filosofiese woorde in dié verband:

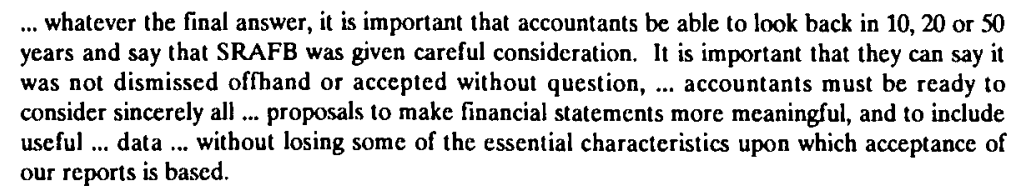

\section{SLOT}

In hierdie artikel is die aard van en die agtergrond tot sosiale verantwoording aangedui, probleme geïdentifiseer ten opsigte van ontwikkelings op dié gebied, en die rol van die rekenmeestersprofessie ten opsigte daarvan oorweeg. In 'n volgende artikel sal verskillende benaderings tot sosiale rekeningkunde bespreek word. 


\section{Bibliografie}

ABT, C.C. 1977. The social audit for management. New York : Amacom.

BAUER, R.A. \& FENN, D.H. 1972. The corporate social audit. New York : Russel Sage Foundation.

BEBBINGTON, J. \& GRAY, R, 1990. The greening of accountancy - Accounting for a better environment. Accountants' Joumal, 35:17-20.

FETYKO, D.F. 1975. The company social audit. Management Accounting, 56:31-34

FRANCIS, M.E. 1973. Accounting and the evaluation of social programs: A critical comment. The Accounting Review, XLVIII(2):245-257.

GRAY, R. 1990. The accountant's task as a friend to the earth. Accountancy, 105:65-68.

HEATON, H. 1965. Economic history of Europe. London : Harper \& Row Publishers. Inc.

HURLEY, J.F. 1982. Social responsibility accounting for business. Lincoln. (Ongepublisecrde proefskrif - The University of Nebraska.)

LUBBE, D.S. 1988. Sosiale verantwoordelikheid van ondernemings met spesiale verwysing na verslagdoening en die oudit. Bloemfontein. (Ongepubliseerde verhandeling - Universiteit van die Oranje-Vrystaat.)

LUBBE, D.S. 1991. Argumente oor sosiale verantwoordelikheid: 'n Oorsig. Acta Academica, 23(1):2242.

MARLIN, J.T. 1973. Accounting for pollution. Joumal of Accounting, 135(2):41-46

MATHEWS, M.R. 1984. Towards a more socially relevant accounting. New York : Praeger

RUBENSTEIN, D. 1989. Black oil red ink. CA Magazine, 122(11):28-35.

STINER, F.M. 1978. The attitudes of certified public accountants towards social accounting: A survey of national and Nebraska opinion. Lincoln. (Ongepubliseerde proefskrif - The University of Nebraska.)

STOREY, R.K. 1981. Conditions necessary for developing a conceptual framework. Financial Analysts Joumal, 37:51-58.

TINKER, T. 1985. Paper prophets: A social critique of accounting. New York : Praeger. 